the Cutting Edge." Worldriew, June). Having been involved, on and off and in various ways, with the World Student Christian Federation for more than twenty years. I find the article right on target with respect to that organization.

And that is tragic. Many American Christians owe huge debis to the WSCF-sponsored evangelists, social critics, and theologians who visited the United States in the period ending 1960. Without the challenges and the testimony given by these sisters and brothers, the faith of many would be far thinner, far more provincial, selfsatisfied, and chauvinistic, and. I believe, far less faithful to the Lord of the Church and of the earth.

We have never been in such deep need, as Americans, for such reproof and heartening as can come to us only from Christians overseas. But I know of no way in which that can begin to happen again unless our American churches representatives are ready and able to change the style of their involvement. Neither "protest" nor "withdrawal" is likely to change much. What is needed is a voice or two that in fact represent at its best the church body in question, rather than toeing the "line" or remaining silent-and by so much impoverishing both the American churches and international Christian community.

Gilbert E. Doan, Jr. National Lutheran Campus Ministry Philadelphia. $P$ a.

\section{Human Rights $\&$ the Paris Agreements}

To the Editors: With regard to the situation of human rights in Vietnam lappropos the three articles in Worldvien's April issue that deal with this subject], it might be mentioned that the people of southern Vietnam were ensured a number of rights in the Paris Peace Agreements. In Article $9 \mathrm{~b}$ the United States and the Democratic Republic of Vietnam pledged to respect the right of the South Vietnamese people to "decide themselves the political future of South Vietnam through genuinely free and democratic general elections under international supervision." In Article 11 the two South Vietnamese parties pledged to respect the "democratic liberties of the people: personal freedom, freedom of speech, freedom of the

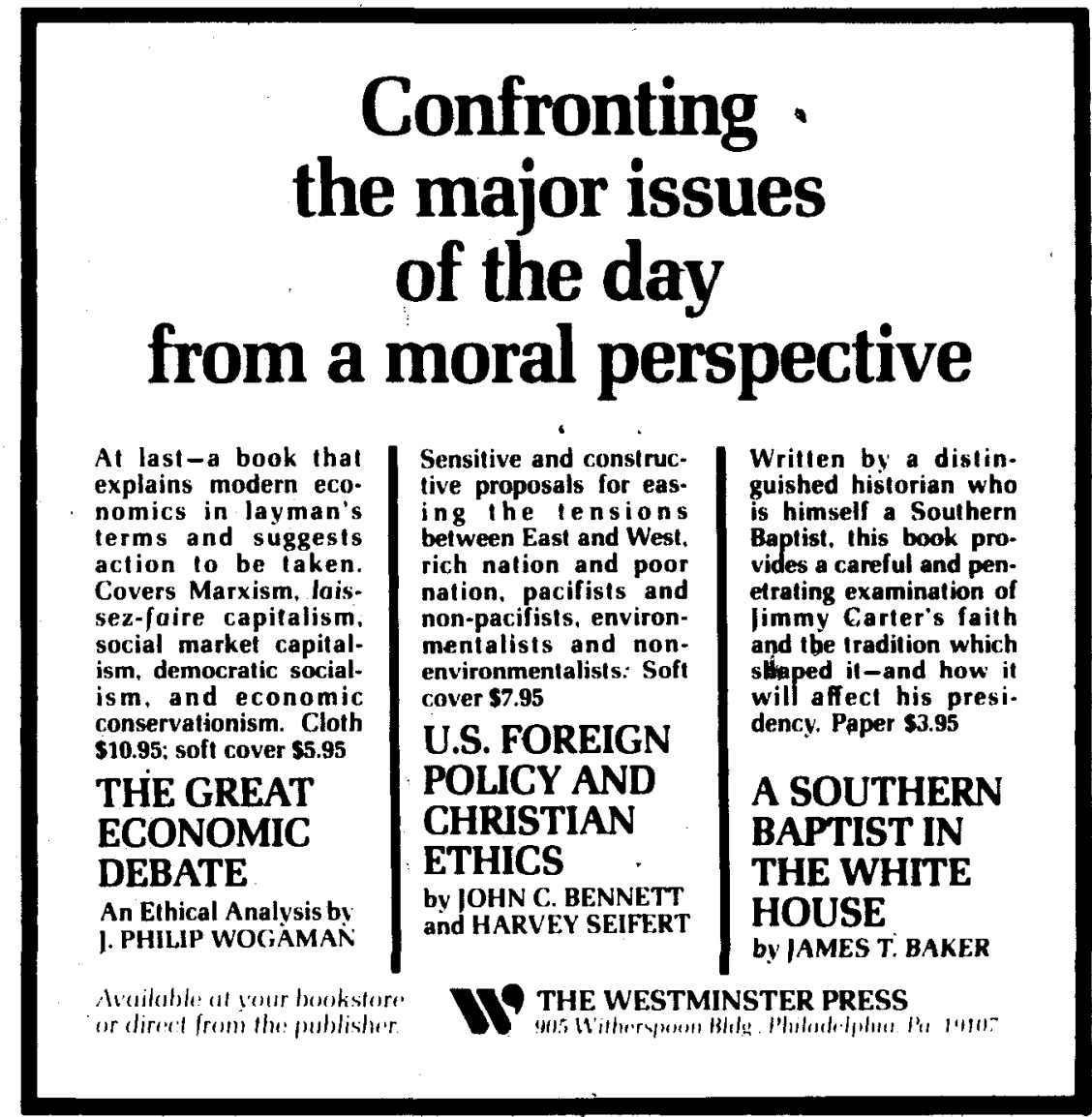

press, freedom of meeting, freedom of organization, freedom of political activities, freedom of belief, freedom of movement, freedom of residence. freedom of work, right to property own. ership, and right to free enterprise." Article 11 also prohibited "all acts of reprisal and discrimination against individuals or organizations that have collaborated with one side or the other."

Now that the Provisional Revolutionary Government and the Democratic Republic of Vietnam have merged into the Socialist Republic of Vietnam, it would seem that the new government is legally obliged to respect both Articles $9 \mathrm{~b}$ and 11 . This would be particularly true because the new government has recognized the Paris Peace Agreements as still legally binding by stating that the United States is obligated. not just morally but legally, to respect the commitments it made in the agreements.

Steve Denney

Portland, Ore.

\section{The "Socialist/Capitalist Dichotomy"}

To the Editors: Michael Novak states in "An Underpraised and Undervalued
System" (Worldview'. July/August) that "Democratic capitalism can function successfully only in certain typess of cultures, in which high values of individual responsibility, social cooperation, and the voluntary spirit have for centuries been nouristied."

Would this be essentially different from asserting... Democratic capitalism can function successfully only in at socialistic climate?

Is there any real basis for the socialistic-capitalistic dichotomy that we so fondly cherish?

Robert C. Peterson

Trimont, Minn.

\section{Books by Editors}

It is our policy not to review. but simply to bring to the altention of our readers. books written by editors of this journal.

In recent weeks Facing Up w Modernity: Excursions in Socien. Politics, and Religion, by Peter L. Berger. was issued by Basic Books (233 pp.; \$11.50). Christian Fuith and Public Policy: Thinking and Acting in the Courage of Uncer rainty, by Richard John Neuhaus. was issued by Augsburg Publishing House (224 pp.: \$4.95 [paper]). 